\title{
A COMPARATIVE ASSESSMENT OF HOUSING DYNAMICS IN ABU DHABI AND DOHA
}

\author{
Hatem Ibrahim,1 Ashraf M. Salama,2 Florian Wiedmann,2 and Reem Awwaad1 \\ 1. Department of Architecture and Urban Planning, College of Engineering, Qatar University \\ 2. Department of Architecture, College of Engineering, University of Strathclyde
}

*Corresponding author's email: hatem_ibrahim@qu.edu.qa

\begin{abstract}
Abu Dhabi and Doha have evolved rapidly in the twentieth century due to the investment of oil and gas revenues. The fast economic growth resulted in an extensive period of urbanization. The various urban dynamics had a great impact with regards to new housing typologies during the last few decades. Doha's housing market is studied in comparison with Abu Dhabi's market considering their population growth rates, real estate market conditions, socio-cultural characteristics, and political approaches. The study is focused on the period from 2004 to 2013 where rapid urban development took place in both cities. The comparative assessment is based on three key aspects: housing typologies, housing distribution, in addition to housing supply and demand. The paper highlights that the urban growth in both cities is initiated via government investments, especially in the real estate market. This is reflected in the case of very similar housing dynamics in both cities. A gradual replacement of low-rise residential villas by high-rise residential towers (apartments/ penthouses) is currently observed in both cities.
\end{abstract}

Keywords: Housing development; housing dynamics; urban growth; residential market; Abu Dhabi; Doha.

\section{INTRODUCTION}

In the age of global interconnectivity, cities need to adapt and provide state-of-the-art infrastructure as well as dynamic real-estate markets. This has exerted a considerable impact on the development of housing typologies and urban development patterns. Generally, the essence of cities is represented in the agglomeration of various housing typologies accommodating all social groups (Ibrahim, 2015). Tracing the development of housing patterns throughout a city's history can provide a general indication of the degree of urbanization that has been achieved, especially in the case of developing countries (Glaeser et al, 2008). In the Arabian Gulf region, capital cities have evolved rapidly during the second half of the twentieth century as a result of oil and gas discovery. It is evident that the Arabian Gulf cities suggest challenging questions about urbanization today. Such questions relatively arise from their showcase architecture and fasttrack development (Mohammad and Sidaway, 2012). Man-made islands, towers, stadiums, museums, and shopping malls are all intertwined with the projection of a global image for these cities (Ibrahim, 2015). During their oil boom period, urban sprawl has occurred leading to scattered urban settlements with low densities, caused by the dominance of suburban housing typologies and a large percentage of vacant lands (Wiedmann et al, 2012). Sprawling suburban developments in these cities suggest considerable challenges related to public expenditures and increased traffic due to the expansion of new housing settlements on the peripheries. This has shaped the dynamics of the housing markets in capital Gulf cities such as Abu Dhabi and Doha.

High population growth rates that are caused by the ongoing migration of expatriates to Abu Dhabi and Doha have shaped very particular dynamics in their housing market. In turn, housing dynamics have caused rapid transformations in lifestyles in both cities. It is noteworthy that Abu 
Dhabi has surpassed Doha in terms of accelerating urban development and global interconnectivity (Hopwood, 2010). In light of that, this paper aims to comparatively assess the dynamics of housing development in Abu Dhabi and Doha in terms of three main assessment aspects: housing typologies, housing distribution, in addition to housing supply and demand. This is conducted in view of the outward similarities between the two cities in terms of their population growth rates, population ethnicity, socio-cultural characteristics, real estate market conditions, and the political drivers for urban development.

\section{RESEARCH APPROACH}

The aim of this section is to introduce the research methodology and period that will aid in achieving the research objective. Considering that Abu Dhabi and Doha have gone through similar contextual evolution and planning approaches, the objective of the paper is to comparatively assess the dynamics of their housing development. A number of similarities between the two cities are found to justify the comparison, as represented mainly in their population structure, economic conditions, and political approaches. Therefore, selecting the appropriate tools, defining the study period, and identifying the comparison criteria will qualify the research objective.

\section{Study Period}

The study is based on the period of housing and real estate acceleration in Abu Dhabi and Doha starting from year 2004 to year 2013. Significant events are traced in Abu Dhabi and Doha related to the cultural, economic, real estate, and political events that took place during this period. Prominently, year 2004 has marked changes to real estate laws in both cities. It was the turning year in their housing development. Changes to property ownership law, which has included ownership rights of land by expatriates, has led to a massive surge in urban development (Murry, 2013). Consequently, two housing laws concerning real estate investment and landlord-tenant relationships have been issued in Abu Dhabi. These laws have opened Abu Dhabi to foreign investment and regulated housing rental procedures. Likely in 2004 in Doha, a law was issued allowing foreign ownership of real estates (Wiedmann et al, 2012). This has marked the beginning of the real estate boom and intensive government-led projects in both cities. In the period between 2004 and 2010, high-rise construction has increased significantly in Doha (Qatar Atlas, 2010). During this period, the government has witnessed an exceptional urbanization boom where the real estate sector has reached peak measures in Doha. Year 2009 was the counter-turning year for both cities. The economy has dropped dramatically, which resulted in the falling of oil prices, which, in turn, resulted in a decline in the real estate market. In Doha, housing prices fell by $40 \%$ as result of that (Qatar Statistics Authority, 2010). However, year 2013 has marked significant economic steadiness in both cities where the residential market has stabilized with good residential sales and commercial standards (Shahbaz et al, 2014) (Figure 1).

\section{Methodology}

In this paper, the analysis of housing dynamics in Abu Dhabi and Doha is based on three main methodologies: literature review of housing statistics, survey of housing typologies, and analytical study to check the integration between the results of the housing survey with the statistical data.

Literature review of statistical data related to housing supply and demand, maps of housing distribution, and population growth rates is conducted by reviewing governmental reports and census studies. This data will lead to a conclusion about the current and future trends in the housing markets in both cities, which, in turn, will aid in comparatively assessing their housing dynamics and future housing tendencies. Statistics of housing supply and demand are evaluated for the period between 2010 and 2013 considering the availability of data for both cities. Maps for 
residential land uses and densities are used to study the spatial distribution of houses, which will give conclusions about their typologies and population ethnicity. Demographic data is analyzed to explore the economic development, population ethnicity, and political planning visions that are dealing with the population growth in both cities.

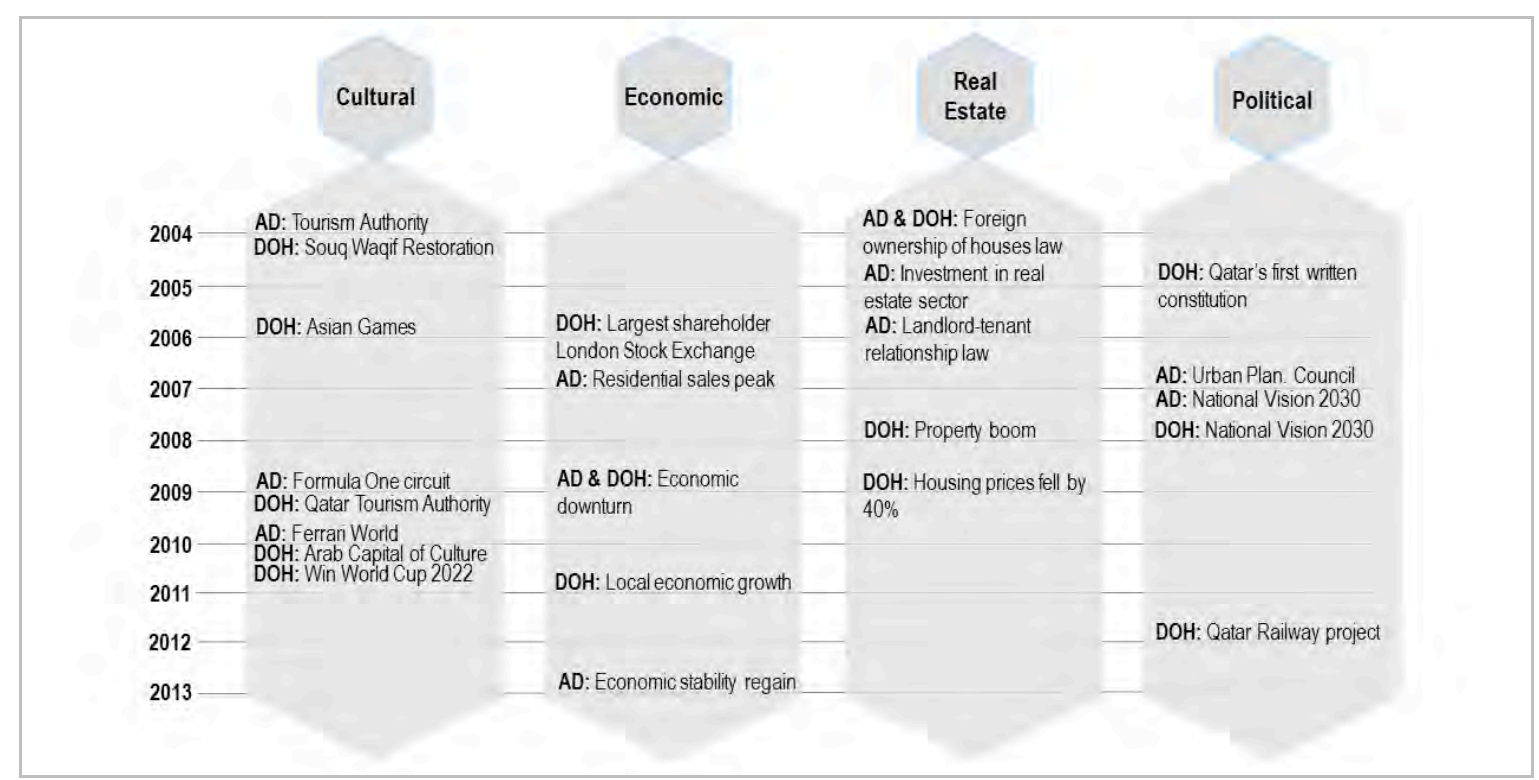

Figure 1. Major events that took place in Abu Dhabi and Doha during the study period (Source: Abu Dhabi Real Estate Market Forecasts, 2010; Qatar Statistics Authority, 2010).

The survey of housing typologies in Abu Dhabi and Doha from 2000 to 2015 is conducted by collecting housing samples of villas and apartments, which were identified as the dominant typologies during this period. A total of sixty housing samples are collected in each city to rach conclusions about the typologies that are favored in the context of multicultural societies. These typologies are defined based on location: downtown, waterfront, and suburban. Abu Dhabi's housing samples have been collected from websites of real estate companies. Doha's housing samples have been collected from architectural firms, real estate companies, and governmental institutions. The analysis of housing typologies is reviewed based on the collected samples to compare between housing development tendencies in both cities. The established criteria for the study include the analysis of the total house area, which is significantly related to preferences of certain housing typologies and affordability measures. It also reflects the socio-cultural preferences of the diverse population, which can inform the dynamics of housing typologies in both cities. Additionally, the established criteria for the study include the percentage of private spaces (bedrooms and bathrooms) in the selected housing samples, which reflects lifestyle tendencies in the housing market in both cities. In general, the selected samples are analyzed to compare the local characteristics of housing in both cities with special focus on the regional particularities. An analytical study is conducted to validate the relation between the housing statistics and the survey of housing typologies in Abu Dhabi and Doha. This will give conclusions about the future of housing dynamics and tendencies in both cities.

\section{HOUSING DEVELOPMENT IN ABU DHABI AND DOHA}

\section{The History of Housing and Urban Growth}

The transformation of Abu Dhabi and Doha from a fishing village to a modern metropolis has occurred with the aid of foreign technical expertise and migrant workers (Murray, 2013). Their 
traditional urban form remained intact until the 1970s when modern urban development began (Kansara, 2016). Both cities had their urban structure evolving based on a grid-like planning pattern that has spread outward respecting the land form (Murray, 2013; Wiedmann et al, 2012). They have gone through almost similar urban development phases that have changed their urban morphology throughout decades (Figure 2). The transition phase has started with the oil discovery. From the late 1940s until the 1970s, oil wealth acted as a catalyst for modern urban growth in both cities (Murray, 2013). The following period was the period of unprecedented urban growth where the first master plans were developed (Salama and Wiedmann, 2013). In 1974, the first master plan for Abu Dhabi was developed in which the downtown area witnessed the first urbanization boom where new housing typologies emerged such as apartments and compound villas (Ghazal, 2013). The adoption of a Western urban design code resulted in a change in the urban morphology of Abu Dhabi (Khirfan et al, 2013). This was the main driver for urban development at that time aiming to build a city of modern character (Horn, 2014). Likely, in 1974, the first master plan for Doha was developed transforming its dense, organic urban fabric into an urban pattern dominated by a grid of ring roads (Salama and Wiedmann, 2013). In the 1990s, Abu Dhabi's housing market rapidly developed in response to the massive population growth rate (Ponzini, 2011). While high-rise residential buildings started to emerge during that time in Abu Dhabi, Doha witnessed a period of stagnation. Yet, a need emerged in the late 1990s to diversify the economy of Doha. The government began to push Doha away from an oil-based economy by investing in education, sports events, infrastructure, and the quality of public realm (Ibrahim, 2013).

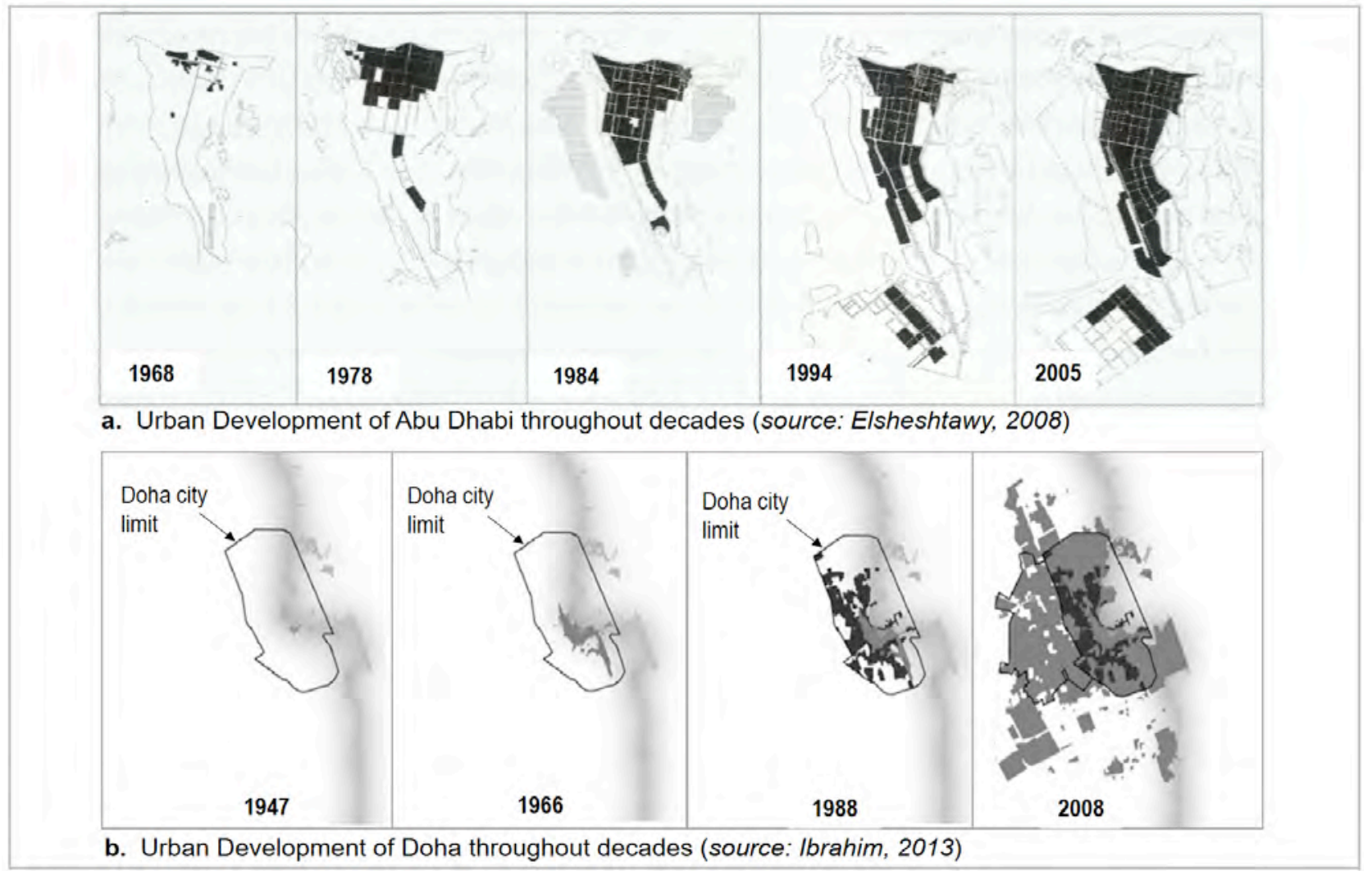

Figure 2. The changing urban morphology of Abu Dhabi and Doha.

A period of new planning visions and strategies has started in the 2000s in both cities. In Abu Dhabi, changes to property ownership law occurred in 2004, including new ownership rights of 
land by foreigners (Murray, 2013). This has led to massive developments and construction projects to satisfy the growing population. The government's national vision 2030 is committed to focusing on housing as the indicative element of its urban growth. This implies that today the main driver for urban development in Abu Dhabi is the political strategy that aims to diversify the economy in the face of diminishing oil reserves. Likely, in the 2000s, Doha has grown fast becoming a key city in the Gulf region. Its fast-growing economy and cultural leadership has made it an urban exemplar in the region (Salama and Wiedmann, 2013). Though, recently, Doha's government has been involved in extensive urban development processes after participating in mega sporting events in the 2000s. These strategies drove Doha to grow rapidly due to extensive migration in all economic sectors. During this period, Doha witnessed new urban development stages where a large number of expatriates gained important roles in the emerging private sector driving urban developments. This is contingent in order to achieve urbanization objectives toward 2030. Therefore, it can be implied that the urban development scenario in both cities took almost the same approach from the 1950s to 2010s. However, Abu Dhabi was seen to be involved in modern urbanization tendencies earlier than Doha due to the decision to establish a diverse city core accommodating various income groups, while Doha's historic center witnessed deterioration. The rapid urbanization in both cities has led to the acceleration of housing expansion in the downtown areas and beyond, announcing the beginning of a newly formed residential fabric. Several housing typologies are included in this fabric in order to meet the diverse preferences of the multi-cultural population.

\section{The Similarities between Abu Dhabi and Doha}

The acceleration of urban development in Abu Dhabi is higher than in Doha. Abu Dhabi was open to foreign investment without considerable limitations in order to be a hub for political, industrial, cultural, and commercial activities. On the other hand, Doha has a conservative approach towards urbanization and global openness, which is confined to its participation in mega sporting events (Elsheshtawy, 2008). Both Abu Dhabi and Doha compete by using the political visions and economic engines for urban development. They have both developed new strategies aiming towards 2030 to sustain developments and to provide a high standard of living. They aspire to define the future with an environmentally, socially, and economically sustainable community (Abu Dhabi Urban Planning Council, 2010; Qatar General Secretariat for Development Planning, 2008). The 2030 national visions of the two cities have emerged from the main urbanization drivers: governmental investments and their direct impact on a growing private sector. This reflects that both Abu Dhabi and Doha have similar positions in which their development has been dependent on government initiatives. The fact of being capital cities justifies this governmental focus. Therefore, the analysis of the dynamics of their housing developments will give insights regarding future development patterns.

\section{ASSESSMENT OF HOUSING DYNAMICS IN ABU DHABI AND DOHA}

\section{Criteria for Housing Comparative Assessments}

Notably, Abu Dhabi and Doha went through similar contextual evolutions and planning approaches. A number of similarities between the two cities are found to rationalize the comparison, being represented mainly in their socio-cultural characteristics, political approach, population dynamics, and the real estate market conditions. The general figures between the two cities (metropolitan city size, number of population, and Gross Domestic Product - GDP) relate to the key comparison criteria (Figure 3). Hence, a pre-assessment of housing dynamics in Abu Dhabi and Doha is carried out to lay grounds for the comparison. Three comparative assessment aspects are defined: housing typologies, housing distribution, in addition to housing supply and demand. They exert considerable influences on the past, present, and future of the urban development of both cities, and, thus, on their housing development. 


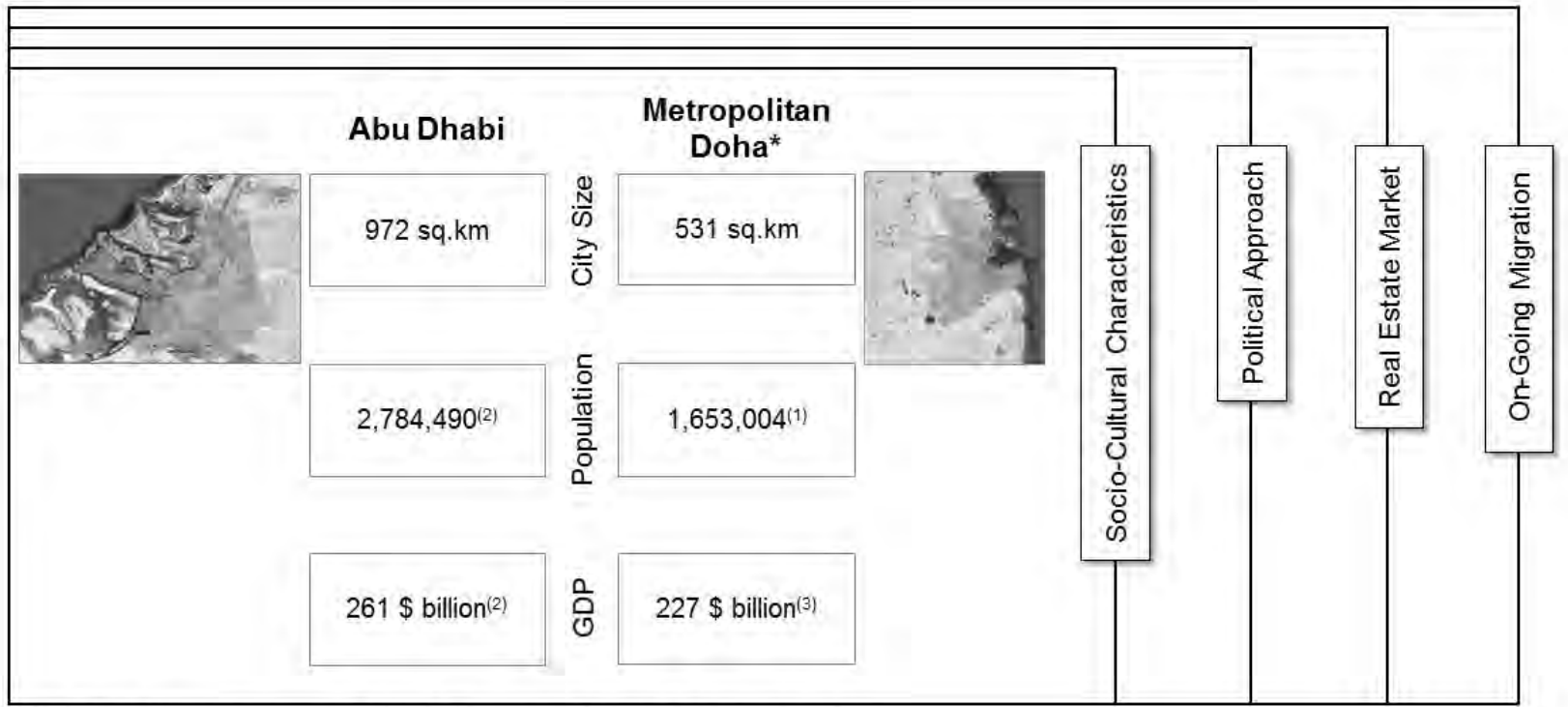

* Including the urban areas in Doha, Al-Rayyan, and Umm Salal municipalities.

Figure 3. Comparison criteria between Metropolitan Abu Dhabi and Metropolitan Doha - Cities Similarities in 2015 (Sources: ${ }^{(1)}$ City Population - UAE and Qatar, 2016; ${ }^{(2)}$ Abu Dhabi Statistics Centre, 2016; and ${ }^{(3)}$ Global Finance, 2016).

Another important criterion is represented in the inflows of expatriates. Following oil discovery and the economic boom in UAE and Qatar, an interesting mix of nationals and expatriates began to emerge as a result of migrations to their capital cities. Generally, the UAE and Qatar share almost similar population structures and ethnic group percentages (Figure 4).

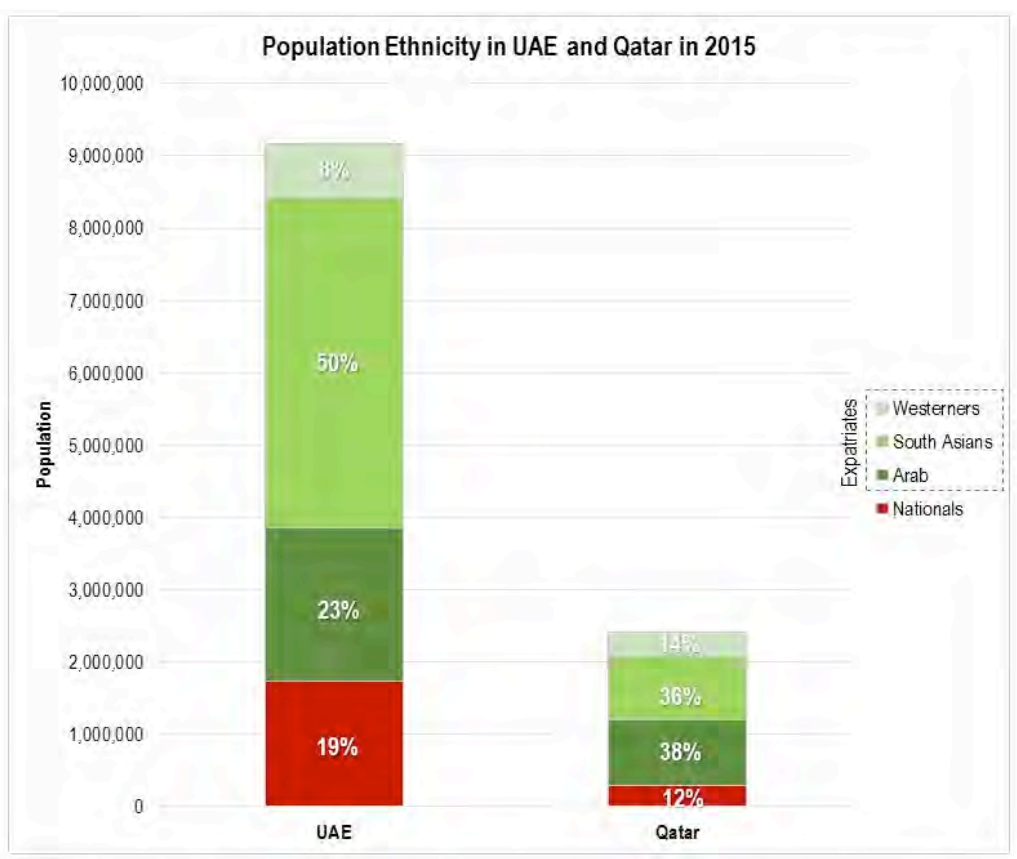

Figure 4. Criteria of population ethnicity in 2015 in UAE and Qatar (Source: IndexMundi, 2016). 
Population growth rate is a fundamental factor for housing demand. In Abu Dhabi and Doha, growth rates of population are mainly due to the ongoing migration of expatriates. Their sociocultural differences require certain housing typologies. Thus, tracing population growth rates in both cities reflects the rapid increases in certain periods of their massive developments. During the period between 1990 and 1995, Abu Dhabi witnessed a considerable increase in population growth rates. This is followed by a steady increase until 2005 where another rapid increase occurred. This was the same period where Doha witnessed its first increase in population growth rates in 2005. It justifies the political approach of each city to invest its oil revenues in massive urban development projects. In the 1990s, the driver for Abu Dhabi's development was the image of a modern city complete with all urban facilities and infrastructure. In the 2000s, the driver for Doha's development was hosting mega-sporting events to present Qatar globally. This is interpreted by an increase in housing demand to accommodate the increasing population.

A prediction for future populations in 2020, 2025, and 2030 attempts to outlook the housing development tendencies in both cities. According to Colliers International Abu Dhabi (2014), the population growth rate of $\mathrm{Abu}$ Dhabi is expected to reach $5.5 \%$ increase per annum. On the contrary, and according to DTZ (2014), a higher population growth rate is expected for Doha accounting for approximately $10.0 \%$ increase per annum. In 2020 , the total predicted population in Abu Dhabi is expected to be around 3.3 million people, whereas in Doha it is expected to be 1.5 million people. In 2030, and considering a higher growth rate for Doha, Abu Dhabi is predicted to have around 5.7 million people whereas Doha is predicted to have around 4 million people (Figure 5).

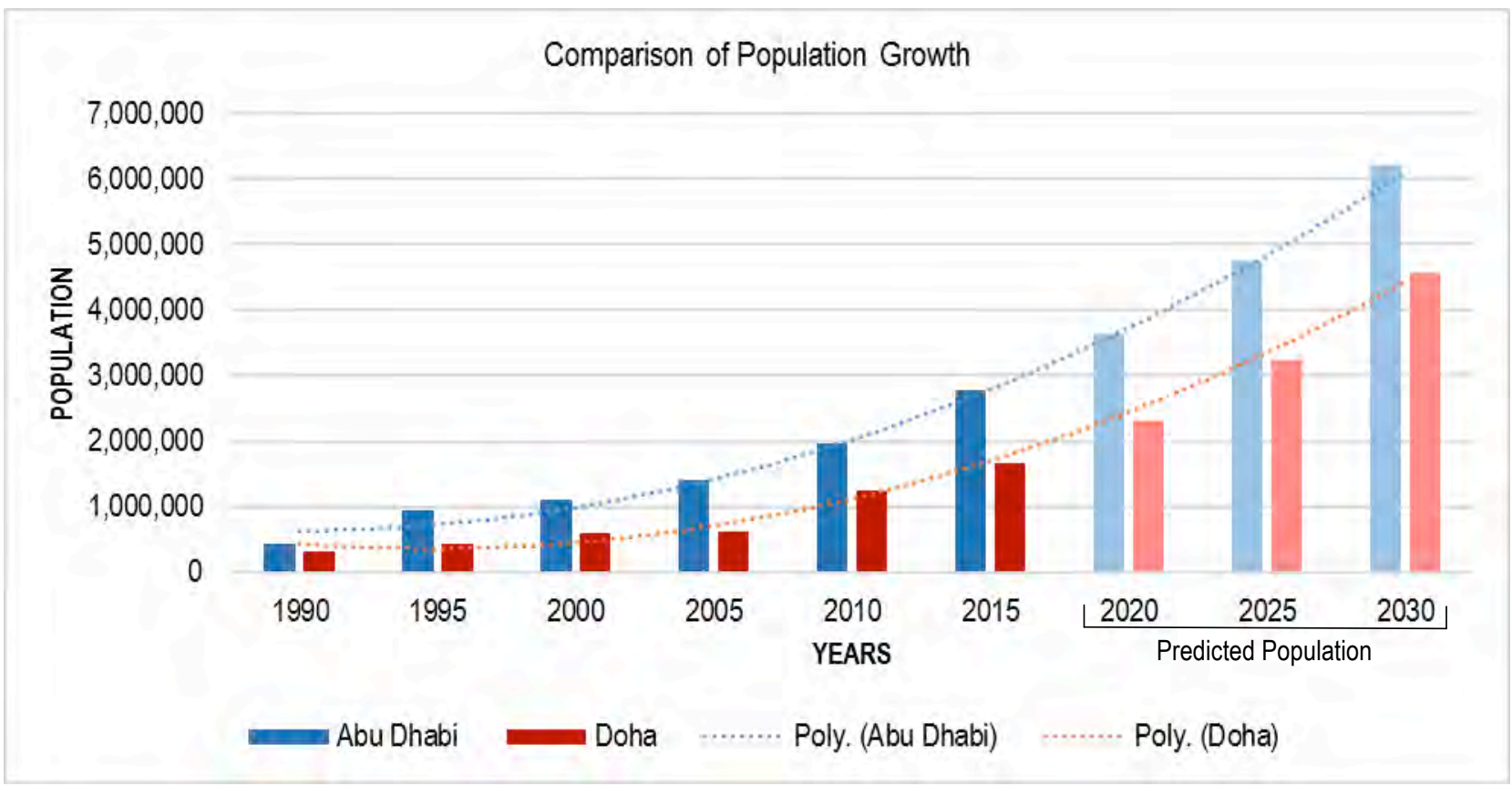

Figure 5. Comparison of population growth of Metropolitan Abu Dhabi and Metropolitan Doha (Source: Abu Dhabi Statistics Centre, 2015; Qatar Statistics Authority, 2010; UAE: City Population, 2016; and Qatar: City Population, 2016).

Since the 1970s, expatriates have made up more than $60 \%$ of Abu Dhabi and Doha's total population. Inflows of expatriates have been guided by the economic boom, which has initiated a great construction boom in both cities (Salama and Wiedmann, 2013) (Figure 6). Abu Dhabi experienced a massive economic boom during the 1970s. At that time, Doha was less focused on urban development and more focused on governmental structuration and political stability 
(Elsheshtawy, 2008). This unique population composition guided the pattern of housing supply and demand in both cities. In fact, their housing markets have been affected by shortage of supply for continuous years with little vacancies (Colliers International Abu Dhabi, 2014; Colliers International Doha, 2014). Housing demand in both cities is expected to continue for the coming years in response to the ongoing urban development processes, which are being driven by the following factors:

- Rapid urban growth due to investments of oil and gas revenues

- Multi-cultural population and diverse housing preferences

- Increasing population rates

Such factors suggest a shift towards a new housing typology in both cities, thus, defining new tendencies in their housing markets.

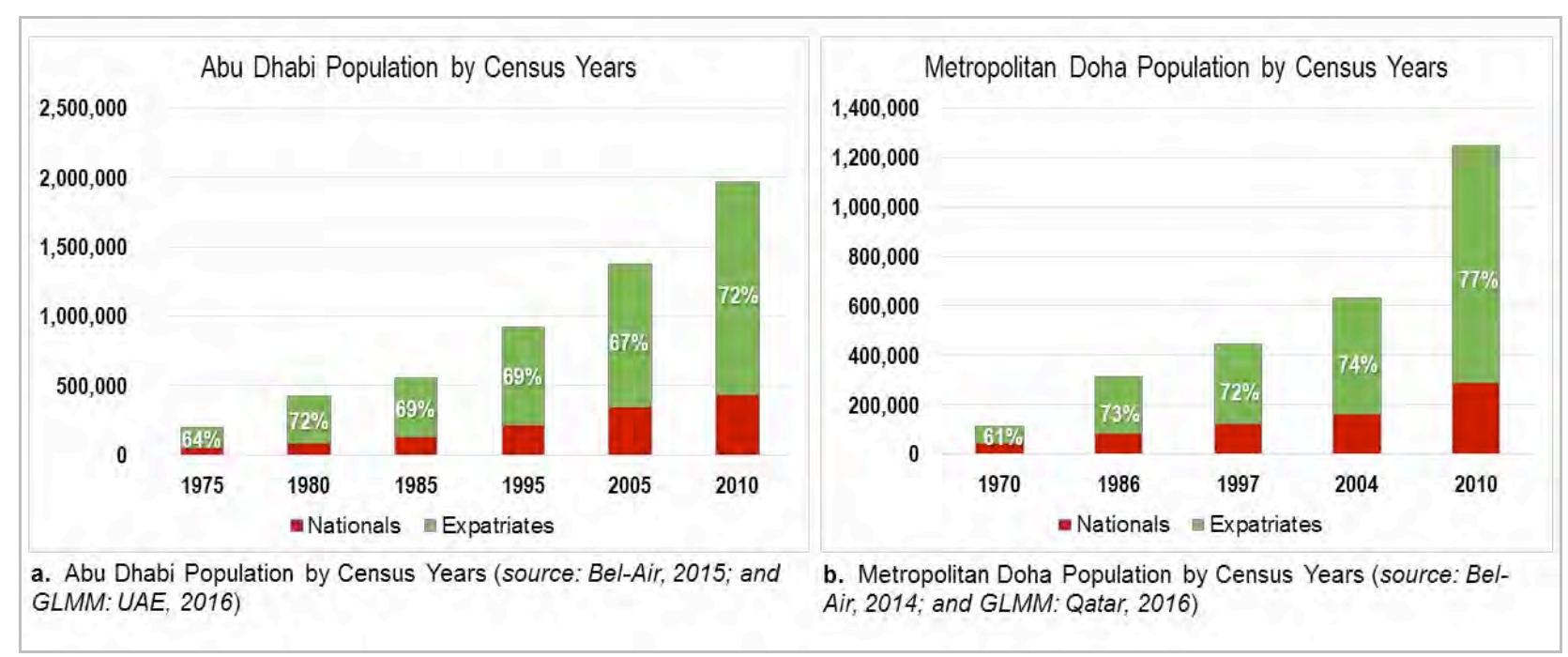

Figure 6. Population estimates of the proportion of expatriates in Abu Dhabi and Doha.

A summary of the historic traces of population growth rates and economic growth rates in both cities attempts to predict the future of Doha's housing with reference to Abu Dhabi's present. The period from 1990 to 2000 in Abu Dhabi corresponds to the period from 2000 to 2010 in Doha where major sporting events have guided urban development. Contiguous to this is the boom in tourism and cultural events. Abu Dhabi witnessed high hotel occupancy rates from 2000 to 2010 with a rate of $70.8 \%$. On the other hand, Doha witnessed a short period of high rates of hotel occupancy with a rate of $71.0 \%$ from 2006 to 2008. This implies that the present focus of Abu Dhabi include boosting tourism towards sustainable economy and urban development, unlike Doha, which is today witnessing great urban and infrastructure development. All of these growth factors indicate that Abu Dhabi's housing and real estate market has developed faster and earlier than that of Doha (Figure 7). 


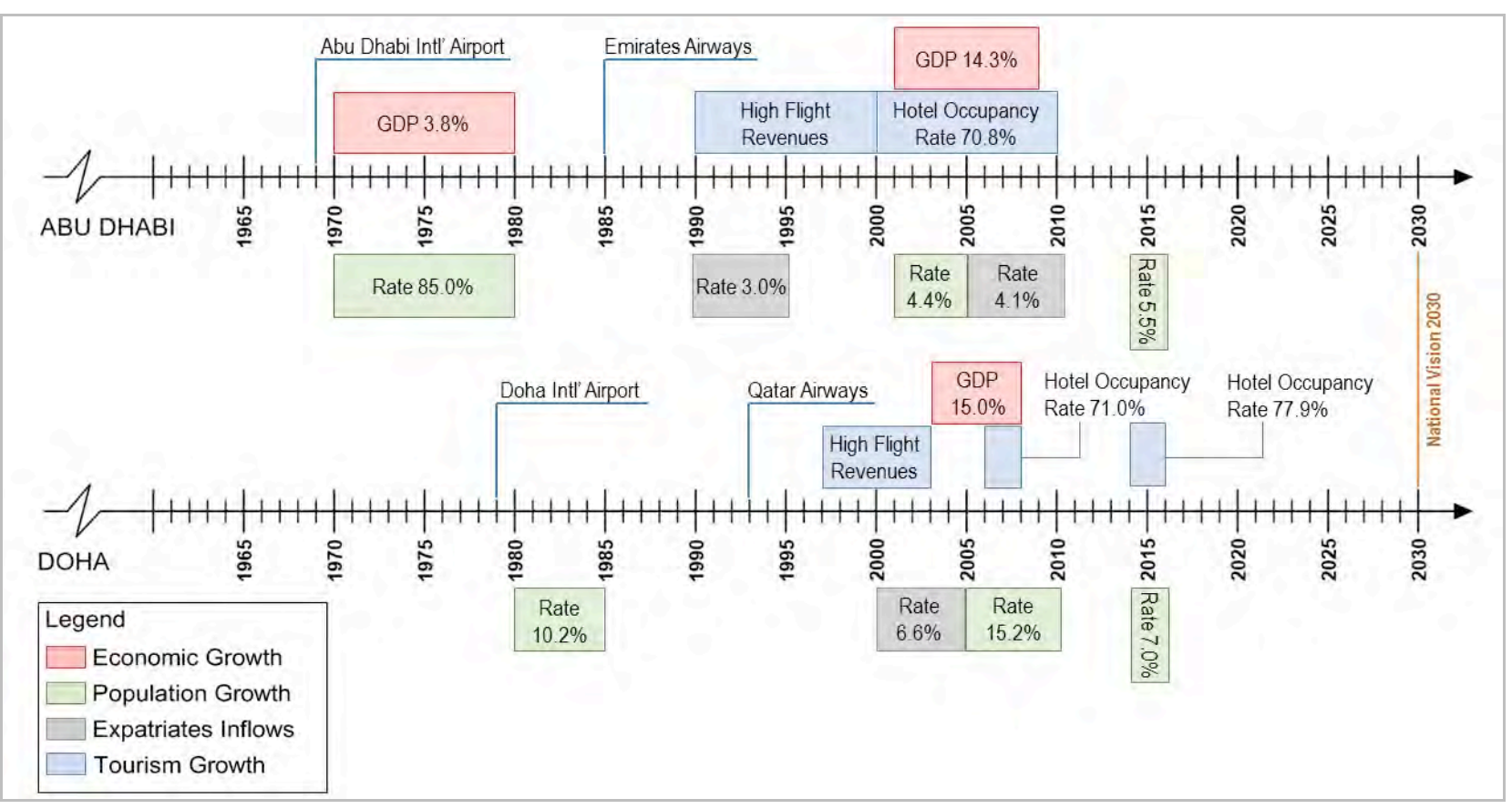

Figure 7. Comparison of the historic traces of urban growth in Abu Dhabi and Doha (Source: Authors).

\section{Urban Governance in Abu Dhabi and Doha}

Abu Dhabi and Doha share common features related to their urban governance, such as monarchical rule and central authority, and the plentiful financial wealth that is generated from their oil and gas production (Tok et al, 2014). Their wealth has contributed to the introduction of comprehensive administrative reform and the need to provide more public services. Public policies have been formulated and implemented in different sectors. By carefully observing Abu Dhabi's urban affairs during the period of spectacular transformation, the new formula for infrastructure development in Abu Dhabi is known to be large-scale projects (Ponzini, 2011). Likewise, Doha is focusing on initiating large-scale projects to push its urban and infrastructure development. A good example is Masdar City in Abu Dhabi and Education City in Doha, both being developed to support their knowledge-based economy. Hence, it can be interpreted that urban development in both cities is governed by political decisions. Economic diversification, education, and cultural preservation are the key visions of various planning efforts (Abu Dhabi Urban Planning Council, 2010; Qatar General Secretariat for Development Planning, 2008). The recent approach of both governments is focused on the use of cultural attractors for triggering urban development (Tok et al, 2014). Consequently, this has affected the residential market and has initiated a housing construction boom at the peripheries of the cities during the last decade (Abdelfattah, 2013). Accordingly, urban expansion in the suburban areas is taking place through the provision of new housing. Also, dynamics of housing supply and demand in both cities are expected to increase, supported by the sound economic conditions and the ongoing migration of expatriates.

\section{Doha Housing Development in View of Abu Dhabi}

In this study, housing dynamics are representatives of the main residential characteristics: housing typologies, housing distribution, in addition to housing supply and demand. Since Abu Dhabi and Doha are found to compete by using the political and economic engines of large-scale projects, a number of aspects are found to affect their housing development tendencies (Al-Sallal 
et al, 2013). These are: population growth rates, population ethnicity, socio-cultural characteristics, conditions of the real estate market, and the country's political approach. These aspects are the research variables that aid in comparatively assessing the housing dynamics in Abu Dhabi and Doha (Figure 8).
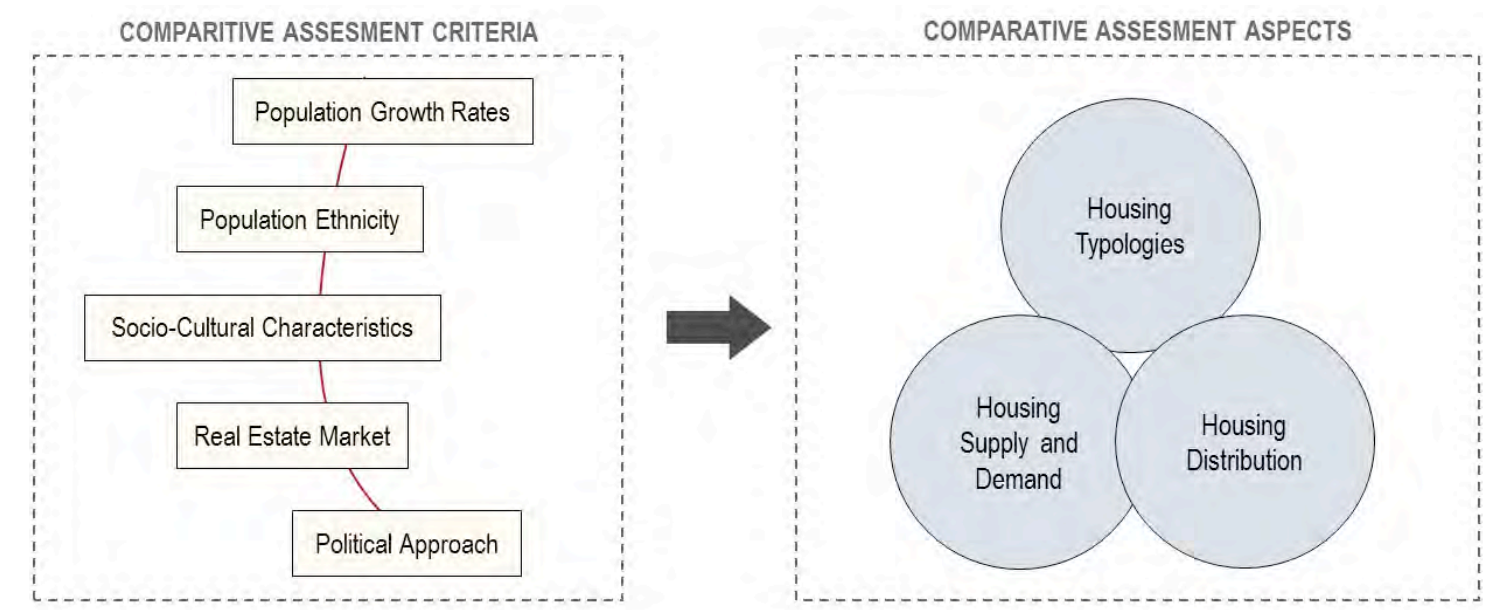

Figure 8. Relation between the comparative assessment criteria and aspects of the housing dynamics in Abu Dhabi and Doha (Source: Authors).

In essence, the figure specifies a series of linkages between the comparative assessment criteria of housing dynamics in Abu Dhabi and Doha and the comparison aspects of these criteria. This is an explicit approach in which the established criteria for comparison will indicate the overall conditions of the housing market in both cities.

\section{Housing Typologies}

A total of sixty housing samples are gathered for Abu Dhabi and Doha to study their housing characteristics and dynamics. Being based on locational distributions, the samples include: waterfront apartments/ villas, downtown apartments/ villas, and suburban apartments/villas. In fact, it must be acknowledged that there are two separate housing markets in both cities based on the population's ethnicity and income groups: houses of high-income groups (mainly nationals) and houses of middle to low-income groups (mainly expatriates). High to middleincome groups tend to afford living in villas, whereas low-income groups tend to afford living in apartments in both cities. Considering the average areas of each typology (Figure 9) and the selected housing samples (Figure 10), spacious villa design and compact apartment design can inform the affordability measures and socio-cultural preferences of nationals and expatriates in Abu Dhabi and Doha. More investment in apartment square meters is dominant in Abu Dhabi. Namely, apartments in Abu Dhabi have larger area as compared to the apartments in Doha. Socio-cultural drivers are found to affect this trend. According to Colliers International Abu Dhabi (2014), the ethnicity of Abu Dhabi's population clearly delineates the demand for housing, where the majority of demand from nationals is for mid to high-end villas, whereas expatriates are far more likely to occupy apartments.

Considering the large size of Emirati households (average of 10 members as per a survey in 2008), villas are seen to satisfy their socio-cultural needs represented in number of bedrooms, family spaces, and private outdoor spaces (Namatalla, 2009). However, the current demand for affordable housing in Abu Dhabi makes the focus on providing different types and sizes of apartments to satisfy the diverse preferences of expatriates. This reflects that Abu Dhabi is investing more in apartment construction, which makes it the popular housing typology there. Therefore, it can be implied that factors of socio-cultural characteristics and population ethnicity 
affect housing typologies in Abu Dhabi making apartments the dominant housing typology. On the other hand, villas are much larger in Doha as compared to Abu Dhabi. According to DTZ (2014), the housing market in Doha is being driven by the consistent and strong population growth rates. Villas are mainly occupied by Qataris who represent a large portion of the highincome families in the city. In Doha, the demand has been strong for family accommodation, particularly four and five bedroom villas (DTZ, 2014). Yet, apartments are considered the affordable housing choice to a large portion of expatriates, which also satisfies their socio-cultural preferences. Therefore, it can be interpreted that Doha will witness a gradual shift towards apartments following a similar path to Abu Dhabi. Moreover, average sizes of waterfront apartments in Doha are nearly similar to those in Abu Dhabi reflecting the political approach to developing master plan projects satisfying the socio-cultural needs of the high-income expatriates.

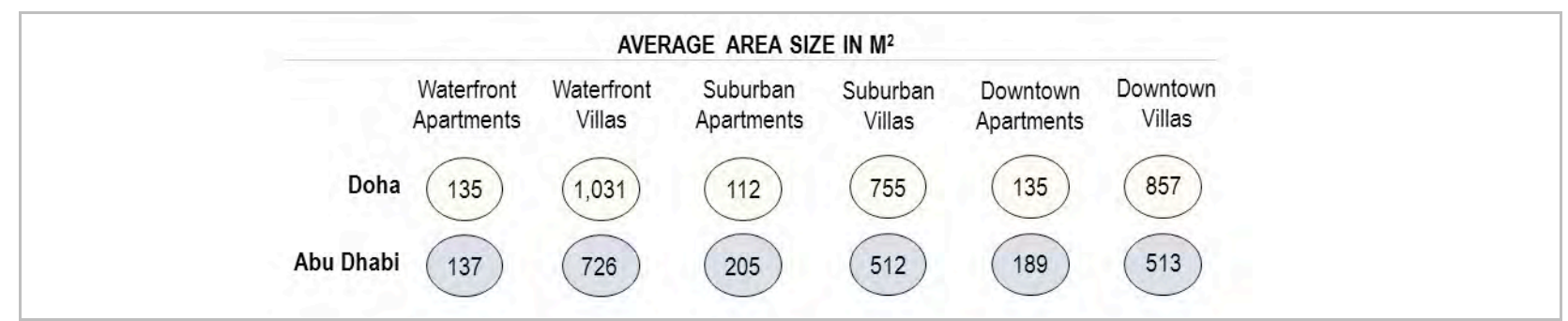

Figure 9. Average total areas of the collected samples per housing typology (Source: Authors).

In reference to the collected samples (2000 to 2015), the percentage of private spaces in villas ranges from $30 \%$ to $40 \%$ leaving more than half of the total living area to semi-private and guest areas. However, a separate guest space is still being built in the house of nationals (majlis) as it used to be in their traditional houses in the past. Today, apartments naturally offer less space for all needed functions. This has led to an adjustment of former local housing trends to global standards in order to accommodate the large majority of expatriates. Therefore, it can be implied that factors of population growth and new multi-cultural realities have led to the similar design of contemporary residences in both Abu Dhabi and Doha. Due to increasing land prices, apartments are kept more compact in design with a maximized use of space and have become the main housing typology for medium income groups in both cities.

\section{Housing Distribution}

In Abu Dhabi and Doha, the first elements of the city's urban structure are represented in the early housing agglomerations on the seashore (old downtown area). Today, the downtown of Abu Dhabi and Doha is located near the sea where reclaimed lands on the shallow waters have defined the boundaries of new waterfront areas. Business areas and busy commercial avenues are located at the downtown of each city leaving neighborhoods and residential quarters to move to the suburban areas.

In Abu Dhabi, the downtown area is dominated by commercial and retail activities. It includes a historical landmark, Qasr Al-Hosn fort, which has once defined Abu Dhabi as a trading hub (Kansara, 2016). The downtown location is dominated by medium to high-density residential uses. Apartment buildings and commercial towers are seen to define the skyline of Abu Dhabi. Away from the downtown area, low-density residential uses are concentrated in the suburban areas. These are partly dominated by the attribution of the square housing plots planned and dedicated to young Emiratis (Horn, 2014). Currently, not all attributed plots are built on, leaving vacant plots for several years between the houses. This has shaped the image of the residential fabric in Abu Dhabi. The residential land use is fairly distributed in the city, with a locational dominance on suburban locations (Figure 11a). 


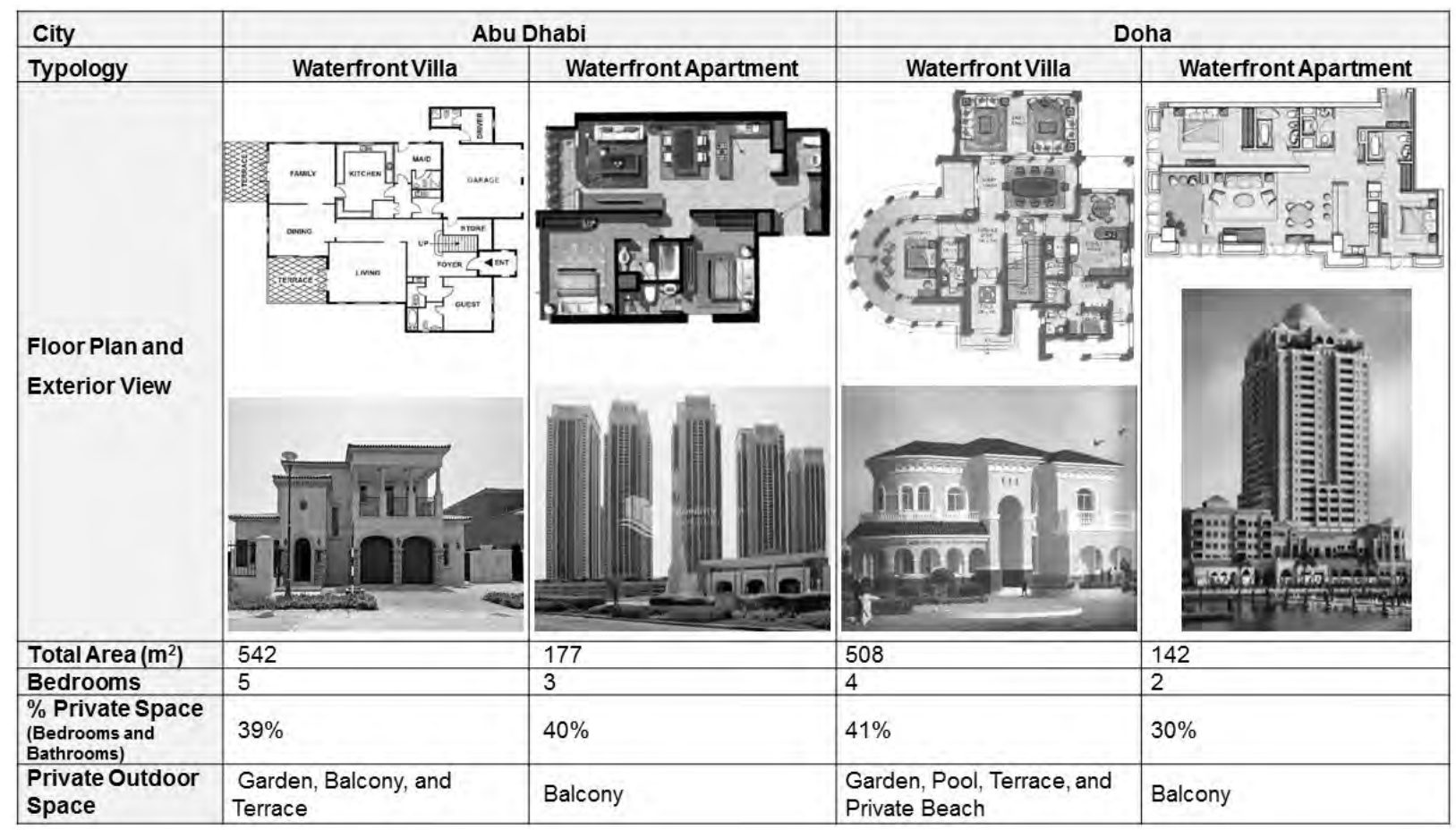

Figure 10. Selected housing samples of waterfront apartments and villas in Abu Dhabi and Doha (Source: Authors).

Similarly, Doha has the greatest concentration of high-density residential land uses in its downtown areas. Apartment buildings reaching up to seven stories are the dominant housing typology in this area. In contrast, low-density residential uses are spreading in the suburban areas. Several large-scale mixed-use projects are taking place in the suburban areas, making Doha's peripheries a potential location for future residential land use growth as it is the case in Abu Dhabi (Figure 11b). It is also noticed that the housing distribution in Doha is clearly demographically segregated, in which nationals prefer living in villas, mostly in suburban areas, while most expatriates live in apartments - one of the reasons being housing affordability (Colliers International Doha, 2014). In 2010, villas have outnumbered apartments being concentrated mainly in suburban areas. This has resulted in apartments being the second major housing typology in Doha. The key housing typologies in both cities are categorized and distributed as follows:

- Villas of nationals (Qataris/ Emiratis) - in suburban locations

- Residential compounds for expatriates - in suburban locations, especially along transition areas and main growth corridors

- Apartment buildings and towers - in downtown locations and fringes

- Exclusive large-scale projects - in different locations in the city, dominantly in waterfront locations

As it can be seen, the distribution of housing typologies is guided by population ethnicity. Nationals tend to live in the suburban locations of the city. In the case of Doha, this is taking place towards the North where new neighbourhoods for Qataris are being developed and clustered. In the case of Abu Dhabi, this is taking place towards the South. The downtown locations are kept for apartment buildings where most of expatriates live. In the waterfront 
locations, exclusive large-scale projects are developed, targeting nationals and high-income expatriates.

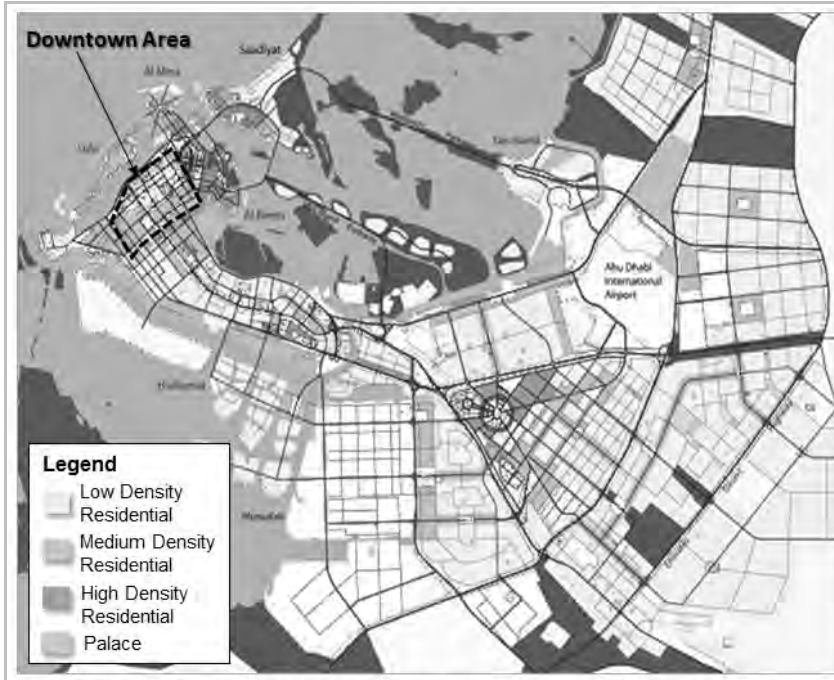

a. Abu Dhabi's Residential Land Use (source: Abu Dhabi Urban Planning Council, 2010)

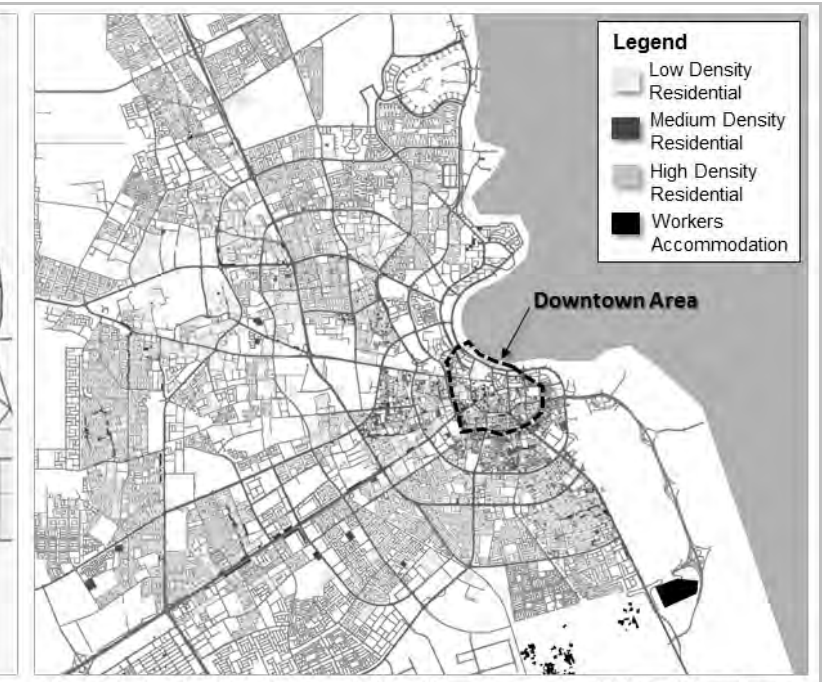

b. Doha's Residential Land Use (source: Qatar Urban Planning Authority, 2008)

Figure 11. Residential land use maps of Abu Dhabi and Doha.

\section{Housing Supply and Demand}

Factors such as high population growth rates and diverse housing preferences have contributed to an increased housing shortage in Abu Dhabi and Doha. In Abu Dhabi, the balance between housing supply and demand has been stable for consecutive years. The steady balance in Abu Dhabi and the increasing balance in Doha inform their state of urban development. Today, Abu Dhabi's housing market is developing at a steady rate reflecting the steady construction activities in the city. In contrast, the housing market of Doha today is developing at an increasing rate reflecting the ongoing increase in construction activities. Despite the increase in housing supply and high population growth rates combined with the diverse housing preferences of the population, it is expected to maintain the demand at high rates (DTZ, 2014).

Supply trends are generally considered to respond slowly to the increasing demand in both cities, particularly in Doha where population growth rates are strong. Abu Dhabi has a slightly stable rate of balance between supply and demand, in which the rate of balance decreased by $1 \%$ from 2010 to 2013. On the other hand, Doha has an increasing rate of balance between supply and demand by $3 \%$ for the same period, making housing supply tendencies slowly responsive to the increasing demand (Figure 12). In both cities, housing demand is represented in the demand for affordable housing where expatriates (middle to low-income) seldom find acceptable rent rates for houses (Colliers International Abu Dhabi, 2014; Colliers International Doha, 2014). In fact, Abu Dhabi's government is keen to supply the residential market with middle to high-end housing that is not affordable to much of its population. Consequently, the balance between supply and demand in Abu Dhabi is slightly stable but the demand for affordable housing is high. This results in a great housing crisis that has led to sharing of housing units (Colliers International Abu Dhabi, 2014). Therefore, it can be interpreted that housing development tendencies in both cities suggest the need for more affordable housing.

The rapid increase in land prices has led to the increase of residential rents and hindered the establishment of more affordable housing. According to DTZ, this demand for affordable housing is slightly lower in Doha (DTZ, 2014). Notably, the shortage of supply in Abu Dhabi's housing market has resulted in a significant degree of sharing housing units, in the form of both 
shared villas and multiple family occupancy of apartments. Likewise, the high shortage of supply has resulted in increasing house prices making the sharing of housing units acceptable to many families and individuals. According to Colliers International Doha (2014), housing demand is clearly defined by nationality. While the majority of Qataris live in villas, the majority of expatriates live in apartments. Therefore, housing demand in Doha continues to rise at an increasing rate throughout the upcoming years as a result of Doha's housing market strongly being undersupplied from 2010 to 2013. During the same period, Abu Dhabi showed a steadily decreasing rate of housing supply and demand, which informs a balance between supply and demand in the future. In general, both cities are facing a major problem in the case of affordable housing demand and supply. This reflects the need to supply the residential market with more apartments targeting expatriates of middle and low income. In recent years, Abu Dhabi has developed a number of high-end projects in a short time frame targeting the high-income population, which has resulted in high residential vacancies, which are higher than the case of Doha.

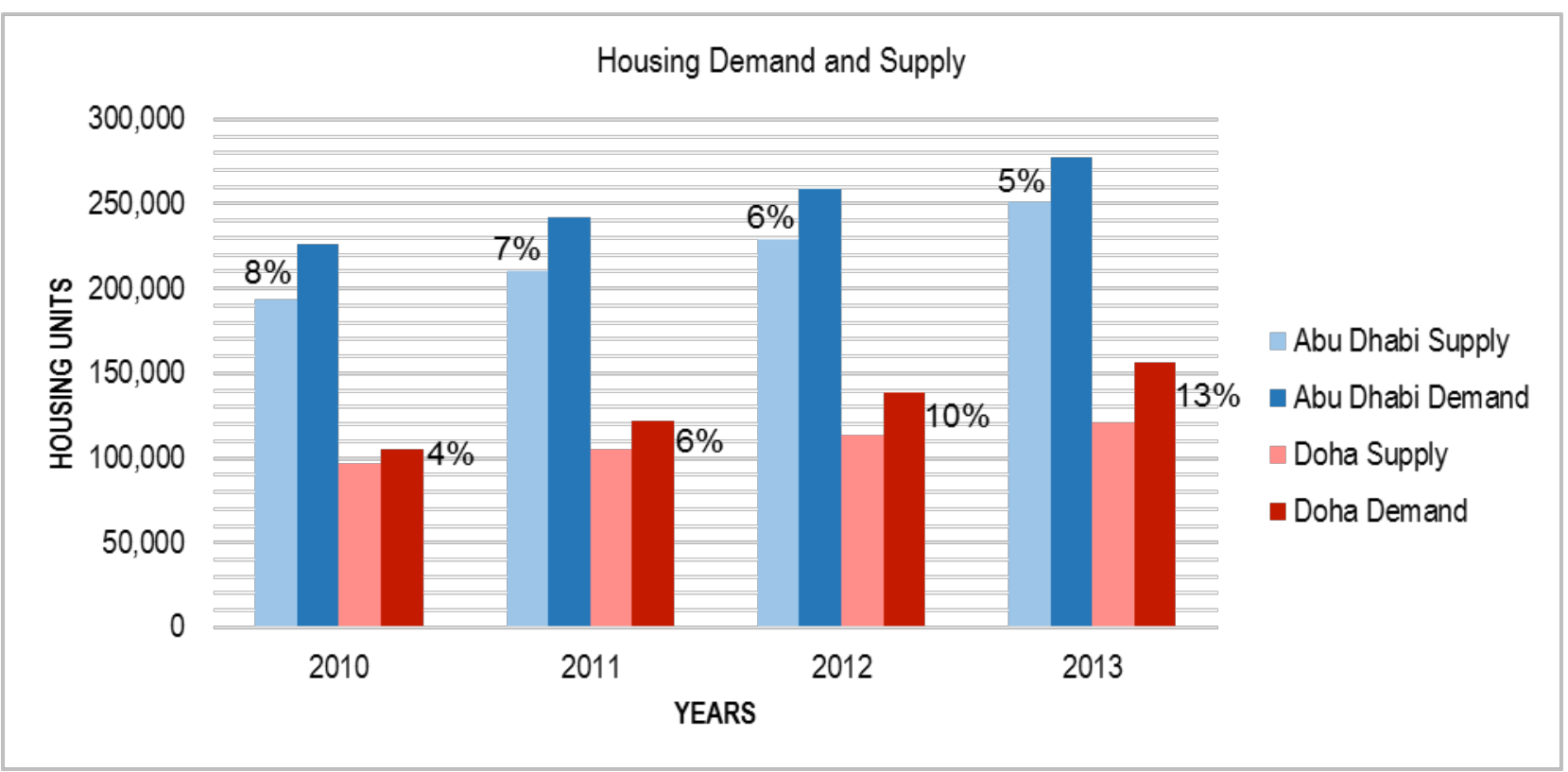

Figure 12. Residential supply and demand in Abu Dhabi and Doha for the period 2010 to 2013 (Source: Abu Dhabi Real Estate Market Forecasts, 2010; Colliers International Doha, 2014)

\section{CONCLUSION}

This study has attempted a comparative assessment of the dynamics that have shaped the housing development in Abu Dhabi and Doha. Both cities are very similar in terms of population growth rates, population ethnicity, socio-cultural characteristics, real estate market, and political approaches. Both cities have witnessed major transformations in their urban development throughout decades. This has been followed by major transformations in their legislative and governmental structures. Future population predictions give insight into the future housing demand where massive construction of residential projects is expected to take place especially in Doha considering the high rate of ongoing migration (Figure 5). This translates the current status of Doha's rapid urban growth similar to Abu Dhabi's urban status. Certain events have shaped their urbanization processes exerting major impacts on the city's urban fabric, especially the residential fabric. Abu Dhabi started high-rise construction in the 1990s and has witnessed a period of administrative and legislative strength in the 2000s. On the other hand, two major sporting events have accelerated the growth of the housing market in Doha: Asian Games in 
2006 and winning the 2022 World Cup bid in 2010. These government-led projects have initiated and prolonged the first construction boom in Doha in the 2000s. Therefore, it can be stated that governmental policies and investments decide on the housing distribution in both cities, which is guided mainly by the availability of infrastructure. Tracing the urban growth of Abu Dhabi since the 1990s gives a predictable indication of Doha's present and future. It is concluded that there is a certain difference in terms of similar events that took place in Abu Dhabi before Doha (Figure 7). Abu Dhabi started its urban growth in the 1990s, whereas Doha started its remarkable urbanization in the 2000s. This difference is warranted to the governmental policies and initiatives to invest the oil and gas revenues for urbanizing the country and its population. This, in turn, reflects the development difference between both cities in terms of housing typologies and their spatial distribution. Therefore, Doha's future housing conditions can be related to Abu Dhabi's present, which implies a greater demand for high-rise apartment typologies in Doha's central areas.

Four housing typologies are concluded in both cities: villas of nationals (Qataris/ Emiratis) in suburban locations; residential compounds for expatriates in suburban locations, especially along transition areas and main growth corridors; apartment buildings and towers in downtown locations and fringes; and exclusive large-scale projects in different locations in the city, especially waterfront locations. This distribution of housing typologies is guided by population ethnicity. Nationals tend to live in suburban locations of the city, which is taking place towards the North of Doha and towards the South of Abu Dhabi (Figure 11). The downtown areas of both cities are more and more dominated by apartment buildings where most expatriates live. Waterfront large-scale projects are initiated by the governments in response to the great housing demand. This reflects the high similarity between the housing market of Abu Dhabi and Doha. The analysis illustrates the phenomena of very similar housing dynamics in both cities, which is represented mainly in their initiated urban growth via government investments, especially in the real estate sector.

Newly emerging economies in both cities have resulted in a new housing demand for certain typologies accommodating differing socio-cultural preferences. The housing market in both cities is clearly defined by nationality. While the national population resides in villas in distinctive suburban locations, the majority of expatriates live in apartments. Due to continuous migration, it can be stated that apartments will witness an increasing diversification process regarding sizes and layouts accommodating the socio-cultural needs of the new population's preferences. The development of apartments has been encouraged by the governments of both cities. Abu Dhabi's shift towards this typology began in the 1990s, which corresponds to the 2000 s in Doha. Therefore, the study the growing expatriate population and their diverse housing preferences. However, most nationals will still prefer the villa typology, which meets their sociocultural needs. A gradual replacement of low-rise suburban houses by high-rise residential towers and apartment blocks is expected in central areas. This is seen to help in providing affordable housing to expatriates.

Today, Doha is in great need for more expatriates to accomplish the construction works towards significant urban development towards its National Vision 2030. This has led to the current population growth rate, which is higher than Abu Dhabi's. In turn, the demand for housing has considerably increased to accommodate the ongoing migration, which is paralleled with an increasing shortage in affordable housing supply. However, this shortage of supply is expected to decrease in the upcoming years towards reaching the 2022 World Cup event. This is justified by the decrease in the ongoing construction rate where most of the large-scale projects and transport infrastructure will be finished (Salama and Wiedmann, 2013). Abu Dhabi's Urban Structure Framework Plan 2030 is developed by the government to respond to current and future development needs, among the most important is to guide the increasing population growth rates (Abu Dhabi Urban Planning Council, 2010). By 2030, it is currently predicted that both cities are 
expected to witness a consolidated housing market when growth rates will be lowered and knowledge economies are expected to replace construction-driven service sectors.

\section{ACKNOWLEDGEMENT}

This paper was made possible by NPRP grant\# [NPRP 07 - 960 - 5 - 135] from the Qatar National Research Fund (a member of Qatar Foundation). The findings achieved herein are solely the responsibility of the author[s].

\section{REFERENCES}

Abdelfattah, M. (2013). Integrated suitability assessment: A way forward for land use planning and sustainable development in Abu Dhabi, United Arab Emirates. Arid Land Research and Management, 27(1), p. 41-64.

Abu Dhabi Real Estate Market Forecasts (2010). Abu Dhabi Urban Planning Council. Retrieved 26 March 2016 from http://www.upc.gov.ae/template/upc/pdf/WEBVERSION.pdf

Abu Dhabi Statistics Centre (2015). Statistical Yearbook of Abu Dhabi 2015. Retrieved 20 May 2016 from https://www.scad.ae/en/pages/default.aspx

Abu Dhabi Statistics Centre (2016). Key indicators. Retrieved 27 September 2016 from https://www.scad.ae/en/pages/default.aspx

Abu Dhabi Urban Planning Council (2010). Abu Dhabi Economic Vision 2030 and Abu Dhabi Urban Planning Vision 2030. Retrieved 26 March 2016 from http://www.upc.gov.ae/template/upc/pdf/abu-dhabi-vision-2030-revised-en.pdf

Al-Sallal, K., Al-Rais, L., \& Dalmouk, M. (2013). Designing a sustainable house in the desert of Abu Dhabi. Renewable Energy, 49, p. 80-84.

Bel-Air, F. (2014). Demography, migration, and labour market in Qatar, explanatory note No. 8/2014. Gulf Labour Market and Migration (GLMM) programme of the Migration Policy Center (MPC) and the Gulf Research Center (GRC). Retrieved 4 June 2016 from http://cadmus.eui.eu/bitstream/handle/1814/32431/GLMM_ExpNote_082014.pdf?sequence $=1$

Bel-Air, F. (2015). Demography, migration, and the labour market in the UAE, explanatory note No. 7/2015. Gulf Labour Market and Migration (GLMM) programme of the Migration Policy Center (MPC) and the Gulf Research Center (GRC). Retrieved 3 June 2016 from http://cadmus.eui.eu/bitstream/handle/1814/36375/GLMM_ExpNote_07_2015.pdf?sequenc $\mathrm{e}=1$

City Population: UAE and Qatar (2016). www.citypopulation.de. Retrieved 28 June 2016 from http://www.citypopulation.de/UAE.html and http://www.citypopulation.de/Qatar.html

Colliers International Abu Dhabi (2014). Abu Dhabi real estate market overview. Retrieved 24 April 2016 from http://www.colliers.com//media/84A0548AB615405C9696EBD7539EBDAF.ashx?la=en-GB

Colliers International Doha (2014). Residential market and affordability levels in Doha: Market performance, trends, and affordability. Retrieved 28 April 2016 from http://www.colliers.com/-/media/562F03BEE6D54CA0B7BA140DF287C911.ashx?la=enGB

DTZ 4th Quarter (2014). Pressure grows on the residential market in Qatar. Retrieved 20 June 2016 from http://dtzqatar.com/wp-content/uploads/Q4-2014-Report.pdf

Elsheshtawy, Y. (2008). The evolving Arab city. London: Routledge.

Ghazal, R. (2013). The man behind Abu Dhabi's master plan. The National: UAE. Retrieved 16 August 2016, from http://www.thenational.ae/uae/heritage/the-man-behind-abu-dhabismaster-plan 
Glaeser, E., Gyourko, J., \& Saiz, A. (2008). Housing supply and housing bubbles. Journal of Urban Economics, 64(2), p. 198-217.

GLMM: Qatar (2016). Gulf Research Center: Gulf Labor Markets and Migration. Retrieved 30 June 2016 from http://gulfmigration.eu/population-by-nationality-qatar-non-qatari-sex-andmunicipality-of-residence-qatar-2010/

GLMM: UAE (2016). Gulf Research Center: Gulf Labor Markets and Migration. Retrieved 30 June 2016 from http://gulfmigration.eu/uae-abu-dhabi-mid-year-population-estimates-bynationality-emiratinon-emirati-and-sex-1960-2010/

Global Finance (2016). Qatar GDP and economic data. Retrieved 27 September 2016 from https://www.gfmag.com/global-data/country-data/qatar-gdp-country-report

Hopwood, D. (2010). Abu Dhabi's Masdar plan takes shape. Renewable Energy Focus, 11(1), p. 18-23.

Horn, C. (2014). Plotting Abu Dhabi - UAE. Urbanplanet info. Retrieved 25 March 2016 from http://urbanplanet.info/urbanism/plotting-abu-dhabi-uae/

Ibrahim, H. (2013). A new paradigm of urban development: Envisioning sustainable futures in Qatar. Sustainable Development and Planning, WIT Transactions on Ecology and The Environment, 173, p. 299-310.

Ibrahim, H. (2013). Contemporary architecture through the concept of regionalism: A sustainable approach for Doha, Qatar. International Journal of Sustainable Human Development, 1(3), p. 94-103. Retrieved 25 April 2016 from http://ijshd.eduservgroup.com/wp/wpcontent/uploads/2014/05/Vol1/ss3-p94-103-Hatem-Ibrahim.pdf

Ibrahim, R. (2015). The elements of traditional urban form in the Arab world. Retrieved 27 March 2016 from https://rafikibrahim.wordpress.com/2015/02/03/the-elements-of-traditional-urbanform-in-the-arab-world/

IndexMundi - Country Facts. (2016). Indexmundi.com. Retrieved 12 May 2016 from $\mathrm{http}: / / \mathrm{www}$.indexmundi.com/qatar/ethnic_groups.html and http://www.indexmundi.com/united_arab_emirates/ethnic_groups.html

Kansara, T. (2016). Transitional zone design in the desert Environment of Abu Dhabi: Vernacular vs. modern. Sustainable Cities and Society, 23, p. 59-67. doi:10.1016/j.scs.2016.02.003

Khirfan, L., Momani, B., \& Jaffer, Z. (2013). Whose authority? Exporting Canadian urban planning expertise to Jordan and Abu Dhabi. Geoforum, 50, p. 1-9.

Mohammad, R., \& Sidaway, J. (2012). Spectacular urbanization amidst variegated geographies of globalization: Learning from Abu Dhabi's trajectory through the LIves of South Asian men. International Journal of Urban and Regional Research, 36(3), p. 606-627.

Murray, M. (2013). Connecting growth and wealth through visionary planning: The case of Abu Dhabi 2030. Planning Theory \& Practice, 14(2), p. 278-282.

Namatalla, A. (2009). Average Emirati household income in Abu Dhabi is Dh47,066. Gulf News: General. Retrieved 3 September 2016 from http://gulfnews.com/business/sectors/general/average-emirati-household-income-in-abudhabi-is-dh47-066-1.500420

Ponzini, D. (2011). Large scale development projects and star architecture in the absence of democratic politics: The case of Abu Dhabi, UAE. Cities, 28(3), p. 251-259.

Qatar Atlas (2010). Qatar Statistics Authority (3rd ed., Vol. 1). Doha, Qatar: Al-Rayyan Printing Press.

Qatar General Secretariat for Development Planning (2008). Qatar National Vision 2030.

Retrieved 2 September 2016 from

http://www.mdps.gov.qa/en/qnv/Documents/QNV2030_English_v2.pdf

Qatar Statistics Authority (2010). Census of population, housing, and establishments. Retrieved 20 June 2016 from http://www.qsa.gov.qa/qatarcensus/Populations.aspx

Qatar Urban Planning Authority (2008). Land use map. 
Salama, A. M. and Wiedmann, F. (2013). Demystifying Doha: On architecture and urbanism in an emerging city. London: Routledge.

Shahbaz, M., Sbia, R., Hamdi, H., \& Ozturk, I. (2014). Economic growth, electricity consumption, urbanization and environmental degradation relationship in United Arab Emirates. Ecological Indicators, 45, p. 622-631.

Tok, M, McSparren, J., Al-Merekhi, M., Al-Ghaish, H., \& Ali, F. (2014). Smart cities in Qatar and United Arab Emirates: A comparative analysis. The Journal of Academic Social Science Studies, 30(1), p. 191-207.

Wiedmann, F., Salama, A. M. \& Thierstein, A. (2012). Urban evolution of the city of Doha: An investigation into the impact of economic transformations on urban structures. METU Journal of the Faculty of Architecture, 29(2), p. 35-61.

\section{AUTHORS}

\section{Dr. Hatem Ibrahim}

Department of Architecture and Urban Planning,

College of Engineering, Qatar University

hatem_ibrahim@qu.edu.qa

\section{Professor Ashraf M. Salama}

Cluster for Research in Architecture and Urbanism of

Cities in the Global South (CRAUCGS),

Department of Architecture,

University of Strathclyde

ashraf.salama@strath.ac.uk

\section{Dr. Florian Wiedmann}

Cluster for Research in Architecture and Urbanism of

Cities in the Global South (CRAUCGS),

Department of Architecture,

University of Strathclyde

florian.wiedmann@strath.ac.uk

\section{Reem Awwaad}

Department of Architecture and Urban Planning,

College of Engineering, Qatar University

reem.y.awwaad@gmail.com 